\title{
Seroprevalence of Toxoplasma gondii and associated alterations in hematology and serum biochemistry of one-humped camels (Camelus dromedarius) in Pakistan
}

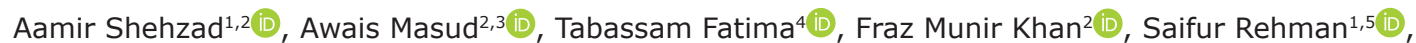

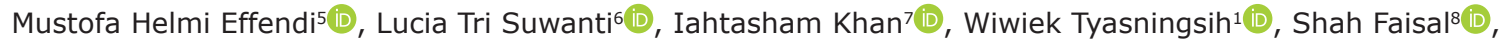 \\ Zain UI Abadeen ${ }^{9}$ and Samreen Bibi ${ }^{10}$ (D)
}

1. Division of Microbiology, Faculty of Veterinary Medicine, University of Airlangga, Surabaya 60115, Indonesia; 2. Livestock and Dairy Development, Government of Punjab, Lahore, Pakistan; 3. Department of Microbiology, Faculty of Veterinary Sciences, University of Veterinary and Animal Sciences, Lahore, Pakistan; 4. Department of Parasitology, Riphah College of Veterinary Sciences, Riphah International University, Lahore, Pakistan; 5. Department of Veterinary

Public Health, Faculty of Veterinary Medicine, University of Airlangga, Surabaya 60115, Indonesia; 6. Department Veterinary Parasitology, Faculty of Veterinary Medicine, University of Airlangga, Surabaya 60115, Indonesia;

7. Department of Clinical Sciences, Section of Epidemiology and Public Health, Jhang Campus, University of Veterinary and Animal Sciences, Lahore, Pakistan; 8. Department of Pharmacy Practice, Faculty of Pharmacy, University of Airlangga Surabaya 60115, Indonesia; 9. Department of Pathology, University of Agriculture Faisalabad, Pakistan; 10. Institute of

Food Science and Nutrition, Faculty of Agriculture, University of Sargodha, Sargodha Division, Punjab, Pakistan.

Corresponding author: Mustofa Helmi Effendi, e-mail: mhelmieffendi@gmail.com

Co-authors: AS: aamir.shezad-2018@fkh.unair.ac.id, AM: adiomianwali2015@gmail.com,

TF: tabassamfatima@gmail.com,FMK: frazmunirkh@gmail.com, SR: saifur.rehman-2019@fkh.unair.ac.id,

LTS: lucia-t-s@fkh.unair.ac.id, IK: iahtasham.khan@uvas.edu.pk,WT: witya_kh@yahoo.com,

SF: shahfaisalpharmacist@gmail.com, ZUA: drzain47@gmail.com, SB: samreen332@yahoo.com

Received: 02-07-2021, Accepted: 10-12-2021, Published online: 23-01-2022

doi: www.doi.org/10.14202/vetworld.2022.110-118 How to cite this article: Shehzad A, Masud A, Fatima T, Khan FM, Rehman S, Effendi MH, Suwanti LT, Khan I, Tyasningsih W, Faisal S, Abadeen ZU, Bibi S (2022) Seroprevalence of Toxoplasma gondii and associated alterations in hematology and serum biochemistry of one-humped camels (Camelus dromedarius) in Pakistan, Veterinary World, 15(1): 110-118.

\begin{abstract}
Background and Aim: Toxoplasma gondii is an intracellular protozoan that infects humans and animals. This study aimed to estimate the seroprevalence of $T$. gondii and the associated alterations in hematology and serum biochemistry of onehumped camels (Camelus dromedarius) in Mianwali district, Pakistan.

Materials and Methods: A total of 350 blood samples were obtained from male and female camels of different ages $(\leq 3$ years old, 4-6 years old, and $\geq 7$ years old). To validate $T$. gondii antibodies, the collected samples were subjected to indirect enzyme-linked immunosorbent assay using purified recombinant micronemal protein 3 as an antibody catching antigen.

Results: The prevalence of $T$. gondii was $50.2 \%$ higher in male camels than in female camels $(16.5 \%)(\mathrm{p}<0.001)$. Furthermore, the prevalence of $T$. gondii in camels was directly proportional to age $(\mathrm{p}<0.001)$. It was $63.33 \%(57 / 90)$ in camels of $\geq 7$ years of age, $32.54 \%$ in $4-6$ years old age group, and $23.08 \%$ in $\leq 3$ years old age group. The hematological analysis of infected camels revealed a significant increase in the values of glucocorticoid-remediable aldosteronism, lymphocyte percentage, monocyte percentage (MONO\%), corpuscular hemoglobin $(\mathrm{MCH})$, and procalcitonin. Furthermore, substantially higher levels of liver enzymes alanine aminotransferase, aspartate aminotransferase, and the macro-mineral potassium were found in the serum of T. gondii-infected camels.
\end{abstract}

Conclusion: The seropositivity of $T$. gondii is directly associated with the age and sex of camels, which may be considered as potential risk factors. Furthermore, T. gondii infection directly impacts the hemato-biochemistry of infected camels.

Keywords: biochemistry, camel, hematology, public health, seroprevalence, Toxoplasma gondii.

\section{Introduction}

The one-humped camel (Camelus dromedarius) is found throughout Africa, South Asia, Australia, and the Middle East [1,2]. The global camel population is estimated to be approximately 35 million [3]. They are an important source of meat and milk in many African

Copyright: Shehzad, et al. Open Access. This article is distributed under the terms of the Creative Commons Attribution 4.0 International License (http://creativecommons.org/licenses/ by/4.0/), which permits unrestricted use, distribution, and reproduction in any medium, provided you give appropriate credit to the original author(s) and the source, provide a link to the Creative Commons license, and indicate if changes were made. The Creative Commons Public Domain Dedication waiver (http:// creativecommons.org/publicdomain/zero/1.0/) applies to the data made available in this article, unless otherwise stated. and Asian countries. Among camelids, the dromedary camels account for $95 \%$ of the world's camel population and produce $2,852,213$ tons of milk and 630,210 tons of meat per year [4-6]. They are one of the less well-studied animals in Pakistan. Pakistan has considerable importance among camel-raising nations, with an estimated population of 1.1 million camels [7]. The camel population is distributed throughout the country; the highest concentration is in Balochistan (41\%), followed by Punjab (22\%), Sindh (30\%), and Khyber Pakhtoon Khwah (7\%) [8]. In Punjab, Pakistan, there are two major camel breeds, Barela and Marecha, which can be found in the Thal desert region of Mianwali district [9]. Camels are known as the "ships of the 
desert;" they are an important mode of transportation in parts of the Thal desert, especially in the district of Mianwali. Camels can become infected with a variety of parasites, including approximately 10 protozoal infections, 48 helminth infections, and approximately 13 species of ectoparasite. The major protozoan genera involved in infection in camels include Babesia, Balantidium, Besnoitia, Cryptosporidium, Eimeria, Neospora, Sarcocystis, Theileria, Trypanosoma, and Toxoplasma [10]. Toxoplasma gondii, an apicomplexan parasite, causes toxoplasmosis in numerous mammals [11,12].

Camels acquire $T$. gondii infection by ingesting sporulated oocysts shed in the feces of cats and other wild animals [13]. Toxoplasmosis causes abortion [14]. The prevalence of $T$. gondii ranges from $3.12 \%$ to $90.9 \%$ in different areas of the world [15-17]. Serological tests have been proven to be a reliable method for detecting $T$. gondii infection in humans and animals $[18,19]$. Enzyme-linked immunosorbent assays (ELISAs) are well known for their sensitivity, flexibility, and cost-effectiveness [20,21]. Some recombinant proteins of $T$. gondii can be expressed in Escherichia coli by binding them to the specific antibodies of $T$. gondii and then can be used for the detection of antibodies of $T$. gondii during serodiagnostic studies [22]. Microneme protein 3 (MIC3) is one of the major adhesive proteins that can bind to both host and parasite cells [23]. Therefore, it is used as an antibody to detect $T$. gondii. The hematology and serum biochemical profile can be used to quickly and accurately assess the status of an animal's health [24]. Furthermore, the biochemical profile can support the molecular understanding of the host-parasite relationship and accurate descriptions of disease [25]. These values are also critical in determining an animal's natural physiological state, nutritional status, and pathological condition [26,27]. In a recent study, Mahmood [28] looked at the effect of T. gondii on hematological, biochemical, and immunological parameters in pregnant women. Infected women had higher white blood cell (WBC) counts, alanine aminotransferase (ALT), aspartate aminotransferase (AST), ALP activities, urea and creatinine concentrations, and interleukin (IL)-6 and IL-10 levels, and lower hemoglobin (HB) and packed cell volume levels.

To the best of our knowledge, no research on the impact of toxoplasmosis on the hematology and serum biochemistry of camels in Mianwali district has been conducted to date. Therefore, this study was planned with the objectives of testing seroprevalence, hematology, and serum biochemistry in the camel population in Mianwali district. The disease-related risk factors in the study area were also observed.

\section{Materials and Methods}

\section{Ethical approval and Informed consent}

Ethical approval for the current study was obtained from the Divisional In-charge of Disease Investigation \& Control Office of Livestock \& Dairy Development Department, Sargodha Division, Punjab, Pakistan. Before the sampling, verbal permission was taken from the camel owners after being briefed on the objective of the study and the blood collection technique. Furthermore, all necessary information about the farmers and their camels were carefully documented.

\section{Study period and location}

The district of Mianwali is situated in the province of Punjab, Pakistan, in the northwestern corner, with latitude 32.585411 and longitude 71.54361700000004. Attock district is in the north, Laki Marwat and Karak districts are in the northwest, and Bhakkar district is in the south. Chakwal and Khushab districts are in the east, while D.I. Khan is in the west. The Indus River runs through the district, starting in the north and splitting it into two unequal parts (Figure-1). The average high temperature per year is recorded as $47^{\circ} \mathrm{C}$, while the average low temperature per year is $19^{\circ} \mathrm{C}$. The mean yearly rainfall is $3.3 \mathrm{~mm}$ and maximum rainfall occurs in July, that is, $6.6 \mathrm{~cm}$. Vegetation type of Mianwali includes wheat, barley, oat, mustard, Eruca, fennel, peanut,

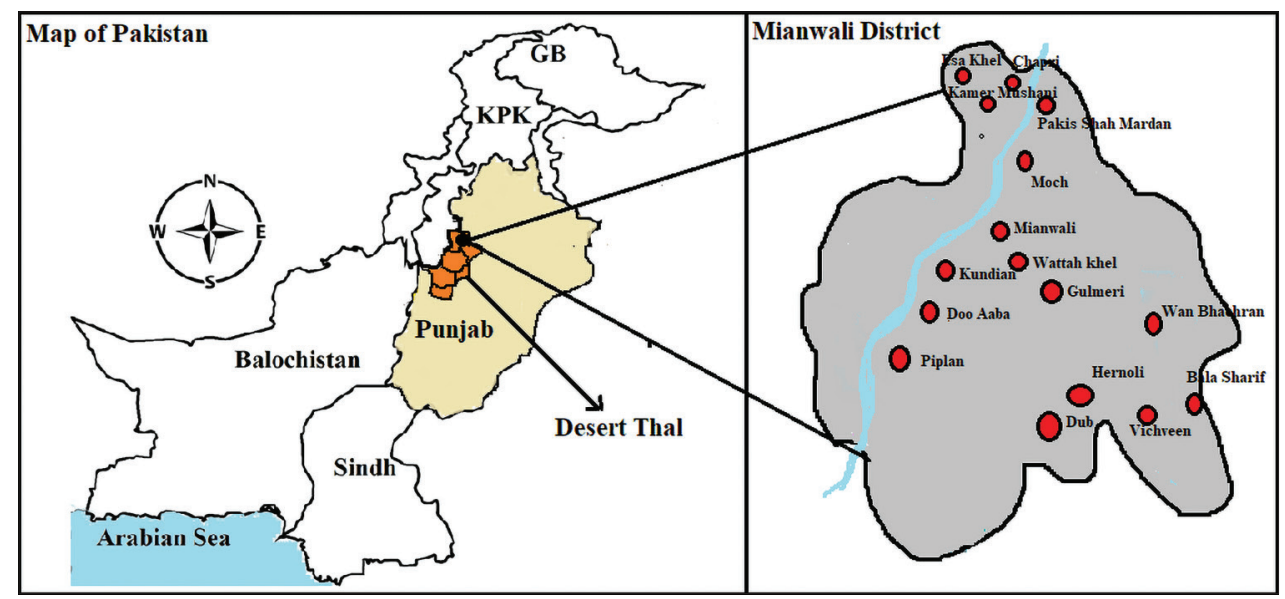

Figure-1: Map shows the Mianwali district's sampling areas located northwest of desert Thal in Punjab, Pakistan. [Source: Humdata.org]. 
mung, and mash. Due to ruthless cutting of forest for fuel and timber purposes, the forests covered area is very low. Mostly the area is semi-arid, very small area is irrigated and source of the irrigation is the canals of river Indus. Mianwali has 905,142 animals, of which 867 are camels. From April 2017 to March 2018, a convenient type of sampling of camels in the district Mianwali was conducted (Table-1).

\section{Questionnaire-based surveillance}

For data collection, a questionnaire was created with open-ended and closed-ended questions and all possible determinants associated with the host, agent, and atmosphere. Formal and informal testing approaches were used for questionnaire development. In total, 350 camels (127 females and 223 males) were included in the study. The animals were divided into three age groups: (1) $\leq 3$ years old; (2) 4-6 years old; and (3) $\geq 7$ years old. The reproductive status of female camels was also registered so that non-pregnant, pregnant, and abortion affected camels could be compared. The influence of breed, production systems (nomadic/ non-nomadic), and the purpose of producing camels also were investigated (milk, meat, and draught).

\section{Blood collection and sera isolation}

Each camel was properly restrained and $5 \mathrm{~mL}$ of blood was collected from the jugular vein through a $10 \mathrm{~mL}$ sterile syringe. The collected sample was directly transferred to the vacutainers without additives (Improvacuter, China). The pure yellow-colored serum was obtained after centrifugation and used for further processing.

\section{Preparation of MIC3 protein}

The previously described method of Jiang et al. [29] was used to purify recombinant MIC3 protein. After induction for $4 \mathrm{~h}$ with isopropyl-D-thiogalactopyranoside, the bacteria (E. coli) that expressed MIC3 protein were harvested. The cells were resuspended in phosphate-buffered saline $(\mathrm{pH} 7.4)$ containing $0.5 \%$ Triton $\mathrm{X}-100,0.1 \%$ lysozyme, and $2 \%$ deoxycholic acid sodium, and then ultrasonically lysed in an ice bath.

\section{Indirect ELISA}

The method described by Fatima et al. [30] was used to conduct indirect ELISA.

\section{Hematological and biochemical analyses}

The Mythic Vet-18 unit was used to perform a complete blood count. The serum chemistry analysis was performed using a semi-automated chemistry analyzer (Photometer 5010v+, Robert Riele GmbH \& Co KG Berlin, Germany. For a total of 20 camels $($ male $=10$ and female $=10)$ positive for toxoplasmosis, hematological analyses were performed using an automated hematology analyzer Mythic 18 Vet Woodley Laboratory Diagnostics UK). For the negative control, 20 healthy camels (10 males and 10 females) were included in the study. The findings were then compared to Schalm's Veterinary Hematology reference values for hematological parameters [31].

\section{Statistical analysis}

IBM, SPSS V. 25.0 (IBM Corp., NY, USA) was used to analyze the results. Descriptive statistics were used to interpret the demographic data. A cross-tabulation test was used to explore the demographics and toxoplasmosis outcomes. Pearson's Chi-squared test was performed to determine the difference among the demographic characteristics of the animals. Logistic regression analysis was performed to investigate the

Table-1: Overall prevalence of T. gondii in camels of district Mianwali, Pakistan $(n=350)$.

\begin{tabular}{|c|c|c|c|c|}
\hline \multirow[t]{2}{*}{ Characteristics } & \multirow[t]{2}{*}{ Frequency (\%) } & \multicolumn{2}{|c|}{ Toxoplasmosis } & \multirow[t]{2}{*}{ p-value } \\
\hline & & Positive (\%) & Negative (\%) & \\
\hline \multicolumn{5}{|l|}{ Gender } \\
\hline Male & $223(63.7)$ & $112(50.2)$ & $111(49.8)$ & \multirow[t]{2}{*}{$<0.001$} \\
\hline Female & $127(36.3)$ & $21(16.5)$ & $106(83.5)$ & \\
\hline \multicolumn{5}{|l|}{ Age } \\
\hline$\leq 3$ years & $91(26.0)$ & $21(23.1)$ & $70(76.9)$ & \multirow[t]{3}{*}{$<0.001$} \\
\hline 4-6 years & $169(48.3)$ & $55(32.5)$ & $114(67.5)$ & \\
\hline$\geq 7$ & $90(25.5)$ & $57(63.3)$ & $33(36.7)$ & \\
\hline \multicolumn{5}{|l|}{ Breed } \\
\hline Barela & $268(76.6)$ & $109(40.7)$ & $159(59.3)$ & \multirow[t]{2}{*}{0.063} \\
\hline Marecha & $82(23.4)$ & $24(29.3)$ & $58(70.73)$ & \\
\hline \multicolumn{5}{|c|}{ Reproductive status of female camels } \\
\hline Pregnant & $25(19.68)$ & $7(28)$ & $18(72)$ & \multirow[t]{2}{*}{0.285} \\
\hline Non-pregnant & $92(72.44)$ & $8(8.70)$ & $84(91.30)$ & \\
\hline Aborted & $10(7.90)$ & $6(60)$ & $4(40)$ & \multirow[t]{2}{*}{$<0.001$} \\
\hline Non-aborted & $117(92.10)$ & $15(12.82)$ & $102(87.18)$ & \\
\hline \multicolumn{5}{|l|}{ Purpose } \\
\hline Drought/meat & $324(92.6)$ & $125(38.58)$ & $199(61.42)$ & \multirow[t]{2}{*}{0.430} \\
\hline Milk production & $26(7.4)$ & $8(30.77)$ & $18(69.23)$ & \\
\hline \multicolumn{5}{|c|}{ Camel production system } \\
\hline Nomadic & $24(6.9)$ & $18(75)$ & $6(25)$ & \multirow[t]{2}{*}{$<0.001$} \\
\hline Non-nomadic & 326 (93.1) & $115(35.28)$ & $211(64.72)$ & \\
\hline
\end{tabular}

T. gondii=Toxoplasma gondii 
predictors of toxoplasmosis. Further, the significance of the difference between the stereochemistry means of normal and infected camels was determined with Student's t-test. A 5\% threshold value was set for significance for all these tests.

\section{Results}

Of the 350 camels screened for $T$. gondii, $133(38.0 \%)$ camels were positive (Table-1). In camels that were $\geq 7$ years old, the prevalence rate was $63.33 \%$ (57/90), compared with younger animals (4-6 years old and $\leq 3$ years old), which had prevalence rates of $32.54 \%(21 / 169)$ and $23.07 \%(21 / 91)$, respectively. The results also showed that animals of 4-6 years old and $\geq 7$ years old had a high risk of toxoplasmosis (odds ratio $[\mathrm{OR}]=1.896, \mathrm{OR}=0.991-3.630$, $\mathrm{p}=0.053$ and $\mathrm{OR}=5.178, \mathrm{CI}=2.530-10.598, \mathrm{p} \leq 0.001$ ), respectively. The prevalence was higher in male camels $(50.22 \% ; 112 / 223)$ than in female camels $(16.53 \%$; $21 / 127)(p<0.001)$. Logistic regression analysis predicts that the risk of toxoplasmosis was 6.867 times higher in males than in females $(\mathrm{OR}=6.867$, $\mathrm{CI}=3.098-15.221, \mathrm{p} \leq 0.001)$. $T$. gondii was present in $60 \%$ of aborted female camels $(n=10)$. The result also showed a significantly higher risk of toxoplasmosis in aborted animals compared with the control group $(\mathrm{OR}=7.348, \mathrm{CI}=4.117-13.115, \mathrm{p} \leq 0.001)$. Our findings revealed that the infection rate was higher in pregnant females $(28 \%)$ than in non-pregnant females $(8.70 \%)$. Furthermore, there was no significant association between the seroprevalence of $T$. gondii and reproductive status of female camels (pregnant or non-pregnant), camel breeds, and purpose of production (Table-1) $(\mathrm{p} \geq 0.05)$. T. gondii seropositivity rate was higher in the camel breed Barela (40.67\%) than Marecha (29.26\%) (Table-1). The statistical analyses revealed that the seroprevalence rate was significantly higher in male camels $(50.2 \%)$ than females $(112 / 223)$ $(\mathrm{p} \leq 0.001)$. Moreover, there was a significant association between $T$. gondii infection and camel production system; the seroprevalence rate was higher in nomadic camels $(75 \% ; 18 / 24)$ than in non-nomadic camels $(\mathrm{p} \leq 0.001)$. We also found that non-nomadic camels had a 5.679-fold higher risk of toxoplasmosis compared with nomadic animals $(\mathrm{OR}=5.967, \mathrm{CI}=2.050$ 17.370, $\mathrm{p} \leq 0.001)$ (Table-2).

In T. gondii-infected camels, the lymphocyte percentage (LYMP\%) 59 \pm 16.64 , monocyte percentage (MONO\%) 6.4 \pm 2.46 , corpuscular volume ( $\mathrm{MCV} \mu \mathrm{m}^{3}$ ) $43.2 \pm 17.73$, procalcitonin (PCT\%) $0.15 \pm 0.174$, mean capsular hemoglobin (MCH pg) 20.3 \pm 11.58 , glucocorticoid-remediable aldosteronism $\left(\mathrm{GRA} \times 10^{3} / \mu \mathrm{L}\right)$ $5.45 \pm 9.92$, were significantly higher $(p=0.005)$ than in non-infected camels, and Hemoglobin ( $\mathrm{HB}$ g/dL) $8.56 \pm 3.24$ and hematocrit (HCT\%) $21.8 \pm 10.83$ values were significantly $(\mathrm{p}=0.005)$ lower; non-significant differences were observed for the WBC count $\left(\times 10^{3} / \mu \mathrm{L}\right)$ $13.03 \pm 13.17$, platelets $\left(\mathrm{PLT} \times 10^{3} / \mu \mathrm{L}\right) 232.9 \pm 260.32$, and red blood cells $\left(\mathrm{RBCs} ; \times 10^{6} / \mu \mathrm{L}\right) \quad 19.37 \pm 116.34$ observed in in comparison to the non-infected camels. Furthermore, significant effects on the values of MON $\left(\times 10^{3} / \mu \mathrm{L}\right) \quad 0.9 \pm 1.92$, granulocyte percentage (GRA\%) 34.5 \pm 17.13 , mean capsular hemoglobin concentration (MCHC g/dL) 46.4 \pm 19.02 , mean platelet volume (MPV $\left.\mu \mathrm{m}^{3}\right) 5.8 \pm 1.34, \mathrm{RBC}$ distribution width (RDW\%) 17.5 \pm 9.58 , and platelet distribution width (PDW\%) 27.9 \pm 22.33 were seen in infected camels; however, these values were within the standard range of hematological parameters for camels and were, therefore, considered as normal (Table-3).

In T. gondii-infected camels, liver enzyme parameters, including serum values ALT (U/L) 19.26 1.49

Table-2: Logistic regression analysis of determinants of $T$. gondii in Pakistan $(n=350)$.

\begin{tabular}{|c|c|c|c|c|c|}
\hline Characteristics & Negative & Positive & Odds ratio & CI $(95 \%)$ & p-value \\
\hline \multicolumn{6}{|l|}{ Gender } \\
\hline Female & $106(30.3)$ & $21(6)$ & 1 & - & - \\
\hline Male & $111(31.7)$ & $112(32)$ & 6.867 & $3.098-15.221$ & $<0.001$ \\
\hline \multicolumn{6}{|l|}{ Age } \\
\hline$\leq 3$ years & 70 (76.9) & $21(23.1)$ & 1 & - & - \\
\hline $4-6$ years & $114(67.5)$ & $55(32.5)$ & 1.896 & $0.991-3.630$ & 0.053 \\
\hline$\geq 7$ years & $33(36.7)$ & $57(63.3)$ & 5.178 & $2.530-10.598$ & $<0.001$ \\
\hline \multicolumn{6}{|l|}{ Breed of camels } \\
\hline Marecha & $58(70.73)$ & $24(29.3)$ & 1 & - & - \\
\hline Barela & $159(59.3)$ & $109(40.7)$ & 1.708 & $0.925-3.132$ & 0.087 \\
\hline \multicolumn{6}{|c|}{ Reproductive status of female camels } \\
\hline Non-pregnant & $84(91.30)$ & $8(8.70)$ & 1 & - & - \\
\hline Pregnant & $18(72)$ & $7(28)$ & 0.000 & 0.000 & 1.000 \\
\hline Non-aborted & $102(87.18)$ & $15(12.82)$ & 1 & - & - \\
\hline Aborted & $4(40)$ & $6(60)$ & 7.348 & $4.117-13.115$ & $<0.001$ \\
\hline \multicolumn{6}{|l|}{ Purpose } \\
\hline Milk production & $199(61.42)$ & $125(38.58)$ & 1 & - & - \\
\hline Drought/meat & 18 69.23) & $8(30.77)$ & 0.000 & 0.000 & 1.000 \\
\hline \multicolumn{6}{|c|}{ Camel production system } \\
\hline Nomadic & $6(25)$ & $18(75)$ & 1 & - & - \\
\hline Non-nomadic & $211(64.72)$ & $115(35.28)$ & 5.967 & $2.050-17.370$ & 0.001 \\
\hline
\end{tabular}

T. gondii=Toxoplasma gondii, $\mathrm{CI}=$ Confidence interval 
and AST (U/L) $125.5 \pm 2.75$ as well as urea $(\mathrm{mg} / \mathrm{dL})$ $53.9 \pm 4.50$ and potassium $(\mathrm{mg} / \mathrm{dL}) 7.30 \pm 0.81 \mathrm{lev}-$ els, were significantly $(p=0.005)$ increased, whereas values of magnesium (mg/dL) $2.5 \pm 0.56$ and glucose $(\mathrm{mg} / \mathrm{dL}) 105.4 \pm 18.44$ were found to be significantly decreased and there was a non-significant effect on the values of sodium $(\mathrm{mmol} / \mathrm{dL}) \quad 151.4 \pm 11.24$ and iron $(\mu \mathrm{g} / \mathrm{dL}) 107.5 \pm 39.31$. Although statistically significant effects were noted on creatinine $(\mathrm{mg} / \mathrm{dL})$ $0.72 \pm 0.351$, phosphorus $(\mathrm{mg} / \mathrm{dL}) 4.3 \pm 0.75$, and calcium $(\mathrm{mg} / \mathrm{dL}) 10.3 \pm 1.29$, these values were within the standard ranges for camels and were, therefore, considered normal (Table-4 and Figure-2).

\section{Discussion}

The aim of the present study was to estimate the seroprevalence of $T$. gondii on camels and its effects on the hematology and biochemistry parameters of infected animals in Mianwali district and the risk factors associated with $T$. gondii infection in the studied population. The overall seroprevalence of $T$. gondii was found to be $38 \%$. The prevalence was higher in male camels $(50.2 \%)$ than in female camels $(16.5 \%)$. Our findings are in line with a previous study (40.1\%) recorded by Fatima et al. [30]. Furthermore, the seroprevalence in our study was slightly higher than that found in two different studies of Saudi Arabia (35.8\% and 34.2\%), Somalia (34.4\%), and Africa (36\%) [32-35]. However, our current findings are significantly lower than those published from the Czech Republic (69\%) [36], Iran (65\%) [37], and Turkey (91\%) [17]. The current variation in the seroprevalence of toxoplasmosis may be due to region, climate effects, management system, age, and analytical techniques used in the study [30,38-41].

Our findings for male camels were comparable with the results of studies conducted in the Taif (56.7\%) and Jizan (54.2\%) areas of Saudi Arabia [33]. The current difference in prevalence rates could be attributed to the fact that most farmers use males as draught animals for goods transportation and plowing agricultural fields. These movements of these camels

Table-3: The mean values of hematological parameters in infected T. gondii camels.

\begin{tabular}{|c|c|c|c|c|}
\hline $\begin{array}{l}\text { Parameters of } \\
\text { hematology }\end{array}$ & $\begin{array}{l}\text { Control/normal } \\
\text { range values }\end{array}$ & $\begin{array}{l}\text { Normal/non-infected } \\
\text { camel values Mean } \pm S D\end{array}$ & $\begin{array}{l}T . \text { gondii-infected } \\
\text { camel's values Mean } \pm S D\end{array}$ & p-value \\
\hline WBCs $\left(\times 10^{3} / \mu \mathrm{L}\right)$ & $7-15$ & $11.00 \pm 5.66$ & $13.03 \pm 13.17$ & 0.075 \\
\hline LYMP $\left(\times 10^{3} / \mu \mathrm{L}\right)$ & $3-7$ & $5.00 \pm 2.83$ & $7.1 \pm 6.99$ & $<0.001$ \\
\hline MON $\left(\times 10^{3} / \mu L\right)$ & $0.5-3$ & $1.75 \pm 1.77$ & $0.9 \pm 1.92$ & $<0.001$ \\
\hline GRA $\left(\times 10^{3} / \mu L\right)$ & 1-4 & $2.50 \pm 2.12$ & $5.45 \pm 9.92$ & 0.001 \\
\hline LYMP\% & $25-50$ & $37.50 \pm 17.68$ & $59 \pm 16.64$ & $<0.001$ \\
\hline MONO\% & $2-6$ & $4.00 \pm 2.83$ & $6.4 \pm 2.46$ & $<0.001$ \\
\hline GRA\% & $12-40$ & $26.00 \pm 19.80$ & $34.5 \pm 17.13$ & $<0.001$ \\
\hline $\operatorname{RBCs}\left(\times 10^{6} / \mu \mathrm{L}\right)$ & $7.5-12$ & $9.75 \pm 3.18$ & $19.37 \pm 116.34$ & 0.339 \\
\hline $\mathrm{HB}(\mathrm{g} / \mathrm{dL})$ & $12-17$ & $14.50 \pm 3.55$ & $8.56 \pm 3.24$ & $<0.001$ \\
\hline HCT (\%) & $25-36$ & $30.50 \pm 7.78$ & $21.8 \pm 10.83$ & $<0.001$ \\
\hline $\operatorname{MCV}\left(\mu \mathrm{m}^{3}\right)$ & $32-40$ & $36.00 \pm 5.66$ & $43.2 \pm 17.73$ & $<0.001$ \\
\hline $\mathrm{MCH}(\mathrm{pg})$ & $12.5-16.5$ & $14.50 \pm 2.83$ & $20.3 \pm 11.58$ & $<0.001$ \\
\hline $\mathrm{MCHC}(\mathrm{g} / \mathrm{dL})$ & $42-50$ & $46.00 \pm 5.66$ & $46.4 \pm 19.02$ & $<0.001$ \\
\hline RDW (\%) & $16-20$ & $18.00 \pm 2.83$ & $17.5 \pm 9.58$ & $<0.001$ \\
\hline $\operatorname{PLT}\left(\times 10^{3} / \mu \mathrm{L}\right)$ & $150-400$ & $275.00 \pm 176.78$ & $232.9 \pm 260.32$ & 0.062 \\
\hline $\operatorname{MPV}\left(\mu \mathrm{m}^{3}\right)$ & $3.5-6.5$ & $5.00 \pm 2.12$ & $5.8 \pm 1.34$ & $<0.001$ \\
\hline РCT (\%) & $0.02-0.018$ & $0.019 \pm 0.00141$ & $0.15 \pm 0.174$ & $<0.001$ \\
\hline PDW (\%) & $35-65$ & $50.00 \pm 21.21$ & $27.9 \pm 22.33$ & $<0.001$ \\
\hline
\end{tabular}

T. gondii=Toxoplasma gondii, GRA=Glucocorticoid-remediable aldosteronism, LYMP=Lymphocyte percentage, MONO\%=Monocyte percentage, $\mathrm{WBC}=$ White blood cell, RBC $=$ Red blood cell, $\mathrm{MCHC}=$ Mean capsular hemoglobin concentration, $\mathrm{MPV}=$ Mean platelet volume, $\mathrm{RDW}=\mathrm{RBC}$ distribution width, $\mathrm{PDW}=$ Platelet distribution width, $\mathrm{HB}=$ Hemoglobin

Table-4: The mean values of determinant parameters for serum biochemistry of T. gondii-infected camels.

\begin{tabular}{lcccc}
\hline $\begin{array}{l}\text { Parameters of } \\
\text { serum chemistry }\end{array}$ & $\begin{array}{c}\text { Control/normal } \\
\text { range values }\end{array}$ & $\begin{array}{c}\text { Normal/non-infected } \\
\text { camel values Mean } \pm \text { SD }\end{array}$ & $\begin{array}{c}\text { T. gondii-infected } \\
\text { camels Mean } \pm \text { SD }\end{array}$ & $\begin{array}{c}\text { p-value } \\
\text { Creatinine }(\mathrm{mg} / \mathrm{dL})\end{array}$ \\
Iron $(\mu \mathrm{g} / \mathrm{dL})$ & $0.7-1.4$ & $1.05 \pm 0.49$ & $0.72 \pm 0.351$ & $<0.001$ \\
Sodium $(\mathrm{mmol} / \mathrm{dL})$ & $82-135$ & $104.50 \pm 31.82$ & $107.5 \pm 39.31$ & 0.384 \\
Calcium $(\mathrm{mg} / \mathrm{dL})$ & $145-155$ & $150.00 \pm 7.07$ & $151.4 \pm 11.24$ & 0.146 \\
Phosphorus (mg/dL) & $8-10.3$ & $9.15 \pm 1.63$ & $10.3 \pm 1.29$ & $<0.001$ \\
Urea $(\mathrm{mg} / \mathrm{dL})$ & $3.2-5.9$ & $4.55 \pm 1.91$ & $4.3 \pm 0.75$ & $<0.001$ \\
Glucose $(\mathrm{mg} / \mathrm{dL})$ & $15-45$ & $30.00 \pm 21.21$ & $53.9 \pm 4.50$ & $<0.001$ \\
ALT $(\mathrm{U} / \mathrm{L})$ & $106-119$ & $112.50 \pm 9.19$ & $105.4 \pm 18.44$ & $<0.001$ \\
Magnesium (mg/dL) & $11-14.5$ & $12.75 \pm 2.47$ & $19.26 \pm 1.49$ & $<0.001$ \\
Potassium $(\mathrm{mg} / \mathrm{dL})$ & $1.82-3.77$ & $2.80 \pm 1.38$ & $2.5 \pm 0.56$ & $<0.001$ \\
AST $(\mathrm{U} / \mathrm{L})$ & $4.6-7.1$ & $5.85 \pm 1.77$ & $7.3 \pm 0.81$ & $<0.001$ \\
\hline
\end{tabular}

T. gondii=Toxoplasma gondii, ALT=Alanine aminotransferase, AST=Aspartate aminotransferase 


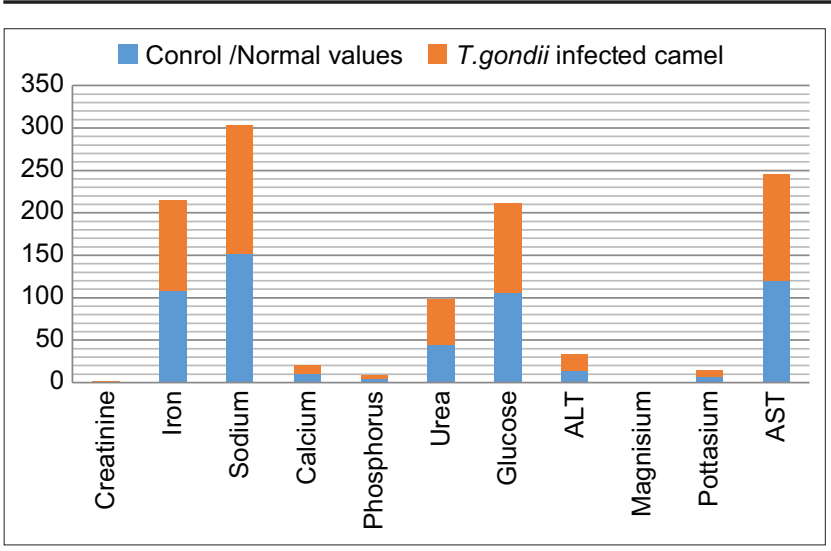

Figure-2: Difference in serum biochemistry values Toxoplasma gondii-infected camels and healthy camels.

into field areas and their browsing habits increase the risk of $T$. gondii infection through the inhalation or ingestion of sporulated oocysts spread by cats in the fields $[13,42]$. The current study found that the seroprevalence rate of $T$. gondii was directly related to the age of camels. Furthermore, as camels aged, there was a significant increase in seroprevalence rate. The highest prevalence rate was found in camels of $\geq 7$ years old. These findings were consistent with those reported by Fatima et al. [30] which indicated that the seroprevalence of $T$. gondii infection was higher in older camels $(70.6 \%)$ than that of youngers ( $4-6$ years; $33.1 \%$, $\leq 3$ years; $18.5 \%$ ). The current high seroprevalence rate of T. gondii in older camels is due to the camels' movement to agriculture fields and feeding in the field areas, where they are more exposed to $T$. gondii compared with younger camels [43]. Moreover, our findings substantiated the research conducted in Algeria, Egypt, Saudi Arabia, and Pakistan, which found that the prevalence rate of $T$. gondii increased significantly with age [44-47]. The prevalence rate was higher in Barela camels (40.67\%) than in Marecha camels. As T. gondii seroprevalence rate is known to vary between different animal breeds [48], this may be one factor responsible for the variation in the findings of the current study. Moreover, the Barela is a potential milking camel breed, and milking camels are more susceptible to $T$. gondii infection than non-milking camels (e.g., Marecha) [30,49].

T. gondii infection was higher in aborted female camels $(60 \%)$ than in non-aborted female camels $(12.82 \%)$. Furthermore, there was a statistically significant $(<0.001)$ correlation between $T$. gondii infection and abortion. These study findings reveal that the leading cause of abortion in female camels is $T$. gondii infection [50]. The prevalence of T. gondii in camels used for draught and raised non-nomadically was higher, consistent with a previous study in Pakistan [30]. In our opinion, the higher prevalence rate in draught camels resulted from their exposure to $T$. gondii in fields. In contrast, the higher prevalence in non-nomadic camels was due to domestic cats contaminating their water and feed sources $[43,51,52]$.
Hematology and biochemistry parameters are the most important physiological tools that reveal the basic information on the diagnosis and prognosis of any disease $[47,53]$. The hematology parameters of GRA, LYMP\%, MONO\%, MCV, MCH, and PCT were significantly increased $(p \leq 0.005)$ in infected camels compared with non-infected camels. Thus, the findings showed that $T$. gondii infection significantly affected the normal hematology parameters in camels; $\mathrm{LYMP} \%, \mathrm{MCH}$, and MCV were notably increased in infected camels [47]. Our findings also support the work of Raisinghani and Lodha [54], Partani et al. [55], Chaudhary et al. [56], Ahmad et al. [57], and Sazmand et al. [58]. Toxoplasmosis induces leukopenia [57], but the WBC\% in our study was different from other studies, which may be due to sample handling procedures [59]. Similarly, the HCT and HB values of infected camels in our study were significantly decreased, which are in line with the study of Lashari et al. [47].

The hematological analysis revealed a significant $(p \leq 0.05)$ reduction in the total RBC count and HB concentration in the infected camels. The low RBC count and $\mathrm{HB}$ concentration are collectively responsible for the cause of anemia in cases of toxoplasmosis infection [60]. HB and HCT were significantly $(\mathrm{p} \leq 0.05)$ lower than the control values. The lower values of HB indicate anemia in infected camels and low HCT values indicate a lower number of blood cells in camels. $T$. gondii infection causes anemia, which is marked by a reduction in HCT [61]. The serum biochemical analysis of infected camels reveals a significant $(p \leq 0.05)$ rise in the levels of liver enzymes, such as ALT and AST. Toxoplasmosis is considered as a liver-damaging disease that causes changes in the liver metabolic processes [62-64]. The variations in the values of ALT and AST are an excellent indicator of hepatic damage. Usually, these enzymes are present in liver, where they are involved in the metabolic processes of amino acids for energy production. However, in the case of hepatocellular injury, these enzymes may leak into the bloodstream, resulting in their increased activity [65]. The results of the current study show an increase in ALT values that were similar to that previously reported in T. gondii-infected camels in Pakistan [47]. The increase in the AST level is attributed to muscular and liver damage. Our findings contradict the AST results of Lashari et al. [47], but completely agreed with the findings of Muhsin et al. [66] and El-Sayed et al. [67]. Moreover, in the current study, higher values of potassium were observed, which increased the risk of renal dysfunction involving creatinine and blood urea nitrogen [61]. Our finding of high potassium level was similar to the results reported in toxoplasmosis-infected cats [61]. In the current study, the glucose values were significantly lower, indicating that $T$. gondii uses excessive glucose for metabolism; these findings agreed with the results of Lashari et al. [47]. 
Some other studies also supported our findings, with increased values of ALT and AST observed in T. gondii infection in other species, including gerbils, goats, dogs, and humans (a study in women only) [68-72]. Increased ALT and AST levels indicate liver dysfunction, which is the primary cause of enzymatic overproduction in the bloodstream [73]. In the current study, the increased urea level was in line with the findings of Lashari et al. [47]. The increase in potassium level was similar to the study by Iewida et al. [61] in T. gondii-infected cats. In contrast, a significant decrease in glucose level was observed in infected camels, which agreed with the study of Lashari et al. [47] and supported the study of Anosa [74], in which the researcher claimed that the parasite consumes glucose during metabolic processes.

\section{Conclusion}

The current study confirmed the significant effects of $T$. gondii infection on hematological and serum chemistry parameters in camels. Further, a direct relationship between camel age and $T$. gondii infection rate was found. The emergence of a high seroprevalence rate of $T$. gondii in camels is a serious public health concern. Therefore, a collaborative effort between public health bodies and veterinary authorities is required to conduct epidemiological studies in various species rearing areas, from which potential eradication and control strategies against T. gondii spread can be introduced. Although the current study yielded some interesting results, it has limitations, including focusing on only one district and small sample size to analyze the prevalence rate and its association with breed, gender, age, reproductive status, and camel production system.

\section{Authors' Contributions}

AM, TF, AS, and FMK: Conceptualization, design, sample collection, and data analysis. SF, AS, and SB: Performed the data entry and statistical analysis. AS, ZUA, and SR: Drafted the manuscript. MHE, LTS, IK, and WT: Revised and finalised the manuscript. All authors read and approved the final manuscript.

\section{Acknowledgments}

The authors acknowledge the camel owners' support and approval of using animals in the current research. The livestock laboratory workers at Disease Diagnostic Laboratory Mianwali,who provided expertise during the analysis, are also praised. This study was funded by Direktorat Riset dan Pengabdian Masyarakat, Deputi Bidang Penguatan Riset dan Pengembangan Kementerian Riset dan Teknologi/ Badan Riset dan Inovasi Nasional, Indonesia (Grant number 420/UN3.15/PT/2021) and Camel Project (PMSSC\&CMP), Punjab, Pakistan (ADP SCHEME NO. GS 3714, LO15002092 GRANT PC-22036 ).

\section{Competing Interests}

The authors declare that they have no competing interests.

\section{Publisher's Note}

Veterinary World remains neutral with regard to jurisdictional claims in published map and institutional affiliation.

\section{References}

1. Kadim, I.T., Mahgoub, O. and Mbaga, M. (2014) Potential of camel meat as a non-traditional high-quality source of protein for human consumption. Anim. Front., 4(4): 13-17.

2. Saeed, M.A., Vaughan, J.L. and Jabbar, A. (2018) An update on sarcocystosis in one-humped camels (Camelus dromedarius). Parasitology, 145(11): 1367-1377.

3. Food and Agriculture Organization. (2021) FAOSTAT Camel Population. Food and Agriculture Organization, Rome, Italy. Available from: http://www.fao.org/dairy-production-products/en. Retrieved on 06 May 2021.

4. Bornstein, S. and Younan, M. (2013) Significant veterinary research on the dromedary camels of Kenya: Past and present. J. Camelid Sci., 6: 1-48.

5. Faye, B., Madani, H. and El-Rouili, S.A. (2014) Camel milk value chain in Northern Saudi Arabia. Emir. J. Food Agric., 26(4): 359-365.

6. El-Alfy, E.S., Abu-Elwafa, S., Abbas, I., Al-Araby, M., Al-Kappany, Y., Umeda, K. and Nishikawa, Y. (2019) Molecular screening approach to identify protozoan and Trichostrongylid parasites infecting one-humped camels (Camelus dromedarius). Acta Trop., 197: 1050-1060.

7. Economic Survey of Pakistan. (2016-17) Economic Advisor's Wing. Ministry of Finance Government of Pakistan, Islamabad, Pakistan. Economic Survey of Pakistan.

8. Pakistan Livestock Census. (2006) Punjab Province Government of Pakistan. The Statistics Division Agriculture Census Organization. Pakistan Livestock Census.

9. Simenew, K.W. (2014) Characterization of Camelus dromedarius in Ethiopia: Production System, Reproduction Performances and Infertility Problems: Ph.D. Thesis. Addis Ababa University, College of Veterinary Medicine and Agriculture, Ethiopia.

10. Parsani, H.R., Singh, V. and Momin, R.R. (2008) Common parasitic diseases of camel. Vet. World, 1(10): 317-318.

11. Boothroyd, J.C. and Grigg, M.E. (2002) Population biology of Toxoplasma gondii and its relevance to human infection: Do different strains cause different diseases? Curr. Opin. Microbiol., 5(4): 438-442.

12. Djurković-Djaković, O., Dupouy-Camet, J., Van der Giessen, J. and Dubey, J.P. (2019) Toxoplasmosis: Overview from a one health perspective. Food Waterborne Parasitol., 15: e00054.

13. Elamin, E.A., Elias, S., Daugschies, A. and Rommel, M. (1992) Prevalence of Toxoplasma gondii antibodies in pastoral camels (Camelus dromedarius) in the Butana plains, Mid-Eastern Sudan. Vet. Parasitol., 43(3-4): $171-175$

14. Chen, X.G. and Tan, F. (2009) Toxoplasma gondii: Past, present and future. Zhongguo ji Sheng Chong Xue Yu Ji Sheng Chong Bing Za Zhi, 27(5): 426-431.

15. Shaapan, R.M. and Khalil, A.F. (2008) Evaluation of different Toxoplasma gondii isolates as antigens used in the modified agglutination test for the detection of toxoplasmosis in camels and donkeys. Am. Eur. J. Agric. Environ. Sci., 3: 837-841

16. Dehkordi, F.S., Borujeni, M.R.H., Rahimi, E. and Abdizadeh, R. (2013) Detection of Toxoplasma gondii in raw caprine, ovine, buffalo, bovine, and camel milk using cell cultivation, cat bioassay, capture ELISA, and PCR 
methods in Iran. Foodborne Pathog. Dis., 10(2): 120-125.

17. Utuk, A.E., Kirbas, A., Babur, C. and Balkaya, I. (2012) Detection of Toxoplasma gondii antibodies and some helminthic parasites in camels from Nevsehir Province of Turkey. Isr. J. Vet. Med., 67(2): 106-108.

18. Kotresha, D. and Noordin, R. (2010) Recombinant proteins in the diagnosis of toxoplasmosis. APMIS, 118(8): 529-542.

19. Bastien, P. (2002) Molecular diagnosis of toxoplasmosis. Trans. R. Soc. Trop. Med. Hyg., 96(Supp1 1): S205-S215.

20. Li, S., Maine, G., Suzuki, Y., Araujo, F.G., Galvan, G., Remington, J.S. and Parmley, S. (2000) Serodiagnosis of recently acquired Toxoplasma gondii infection with a recombinant antigen. J. Clin. Microbiol., 38(1): 179-184.

21. Shanmugham, R., Thirumeni, N., Rao, V.S., Pitta, V., Kasthuri, S., Singanallur, N.B., Lingala, R., Mangamoori, L.N. and Villuppanoor, S.A. (2010) Immunocapture enzyme-linked immunosorbent assay for assessment of in vitro potency of recombinant hepatitis B vaccines. Clin. Vaccine Immunol., 17(8): 1252-1260.

22. Pietkiewicz, H., Hiszczyńska-Sawicka, E., Kur, J., Petersen, E., Nielsen, H.V., Stankiewicz, M., Andrzejewska, I. and Myjak, P. (2004) Usefulness of Toxoplasma gondii-specific recombinant antigens in serodiagnosis of human toxoplasmosis. J. Clin. Microbiol., 42(4): 1779-1781.

23. Garcia-Réguet, N., Lebrun, M., Fourmaux, M.N., Mercereau-Puijalon, O., Mann, T., Beckers, C.J., Samyn, B., Van Beeumen, J., Bout, D. and Dubremetz, J.F. (2000) The microneme protein MIC3 of Toxoplasma gondii is a secretory adhesin that binds to both the surface of the host cells and the surface of the parasite. Cell. Microbiol., 2(4): 353-364.

24. Ramprabhu, R., Chellapandian, M., Balachandran, S. and Rajeswar, J.J. (2010) Influence of age and sex on blood parameters of Kanni goats in Tamil Nadu. Indian J. Small R., 16(2): 249-251.

25. Al-Kaysi, A.M., Eid, R.A.A. and Fahmy, B.G.A. (2010) Biochemical studies on the effect of Toxoplasma infection on liver and kidney functions in mice. Egypt. J. Comp. Pathol. Clin. Pathol., 23(1): 174-185.

26. Opara, M.N., Udevi, N. and Okoli, I.C. (2010) Haematological parameters and blood chemistry of apparently healthy West African Dwarf (WAD) goats. N. Y. Sci. $J ., 3(8)$ : 68-72.

27. Maina, S.M., Gitao, C.G. and Gathumbi, P.K. (2015) Hematological, serological and virological findings in sheep and goats experimentally infected with lineage III peste des petits ruminants virus isolates in Kenya. J. Exp. Biol. Agric. Sci., 13(1): 81-88.

28. Mahmood, O.I. (2018) Effect of toxoplasmosis on hematological, biochemical and immunological parameters in pregnant women in Tikrit city, Iraq. Tikrit J. Pure Sci., 21(3): 24-27.

29. Jiang, T., Gong, D., Ma, L.A., Nie, H., Zhou, Y., Yao, B. and Zhao, J. (2008) Evaluation of recombinant MIC3 based latex agglutination test for the rapid serodiagnosis of Toxoplasma gondii infection in swine. Vet. Parasitol., 158(1-2): 51-55.

30. Fatima, T., Mehnaz, S., Wang, M., Yang, J., Sajid, M.S., Shen, B. and Zhao, J. (2019) Sero-prevalence of Toxoplasma gondii in one-humped camels (Camelus dromedarius) of Thal and Cholistan deserts, Punjab, Pakistan. Parasitol. Res., 118(1): 307-316.

31. Weiss, D.J. and Wardrop, K.J. (2011) Schalm's Veterinary Hematology. $6^{\text {th }}$ ed. John Wiley and Sons, Hoboken, New Jersey.

32. Al-Afaleq, A.I., Elamin, E.A., Fatani, A. and Homeida, A.G. (2018) Parasitic profile of Saudi Arabian camels. J. Camel Pract. Res., 25(1): 93-97.

33. Mohammed, O.B., Amor, N., Omer, S.A. and Alagaili, A.N. (2020) Sero-prevalence of Toxoplasma gondii and Neospora caninum in Dromedary camels (Camelus dromedarius) from Saudi Arabia. Rev. Bras. Parasitol. Vet., 29(1): e019119.

34. Hassan-Kadle, A.A., Ibrahim, A., Yusuf, A. and Vieira, R.
(2018) Serosurvey of Toxoplasma gondii and Brucella spp. In Camels (camelus dromedarius) from Somalia. Conference: $20^{\text {th }}$ Congresso Braileiro de Parasitogia Veterinária At: Parque Governador Ney Braga, Londrina, PR, Brazil. p131-140.

35. Tonouhewa, A.B., Akpo, Y., Sessou, P., Adoligbe, C., Yessinou, E., Hounmanou, Y.G., Assogba, M.N., Youssao, I. and Farougou, S. (2017) Toxoplasma gondii infection in meat animals from Africa: Systematic review and meta-analysis of sero-epidemiological studies. Vet. World, 10(2): 194-208.

36. Bártová, E., Kobédová, K., Lamka, J., Kotrba, R., Vodička, R. and Sedlák, K. (2017) Sero-prevalence of Neospora caninum and Toxoplasma gondii in exotic ruminants and camelids in the Czech Republic. Parasitol. Res., 116(7): 1925-1929.

37. Aliabadi, J. and Ziaali, P.N. (2016) Survey of Toxoplasma gondii in livestock's meat (Sheep, Goat, Camel), using nested PCR method in Sabzavar district. Eur. Online J. Nat. Soc. Sci., 5(2): 368.

38. Afonso, E., Thulliez, P., Pontier, D. and Gilot-Fromont, E. (2007) Toxoplasmosis in prey species and consequences for prevalence in feral cats: Not all prey species are equal. Parasitology, 134(14): 1963-1971.

39. Dabritz, H.A., Miller, M.A., Gardner, I.A., Packham, A.E., Atwill, E.R. and Conrad, P.A. (2008) Risk factors for Toxoplasma gondii infection in wild rodents from central coastal California and a review of $T$. gondii prevalence in rodents. J. Parasitol., 94(3): 675-683.

40. Smith, D.D and Frenkel, J.K. (1995) Prevalence of antibodies to Toxoplasma gondii in wild mammals of Missouri and east-central Kansas: Biologic and ecologic considerations of transmission. J. Wildl. Dis., 31(1): 15-21.

41. Dubey, J.P., Hotea, I., Olariu, T.R., Jones, J.L. and Dărăbuş, G. (2014) Epidemiological review of toxoplasmosis in humans and animals in Romania. Parasitology, 141(3): 311-325.

42. Gebremedhin, E.Z., Yunus, H.A., Tesfamaryam, G., Tessema, T.S., Dawo, F., Terefe, G., Di Marco, V. and Vitale, M. (2014) First report of Toxoplasma gondii in camels (Camelus dromedarius) in Ethiopia: Bioassay and seroepidemiological investigation. BMC Vet. Res., 10(1): 1-2.

43. Gebremedhin, E.Z., Dima, N., Beyi, A.F., Dawo, F., Feyissa, N., Jorga, E., Di Marco, V. and Vitale, M. (2016) Toxoplasmosis in camels (Camelus dromedarius) of Borana zone, Oromia region, Ethiopia: Seroprevalence and risk factors. Trop. Anim. Health Prod., 48(8): 1599-606.

44. Abdullah, M.C., Kamal, M., Karima, B., Samir, A., Hocine, B.M., Dajmal, K., Rachid, K. and Khatima, A.O. (2020) First report of Toxoplasma gondii infection and associated risk factors in the dromedary camel (Camelus dromedarius) population in southeast Algeria. Vet. Parasitol., 22: 100475.

45. Hassan, H.E. (2018) Effectiveness of a structured teaching program on anxiety and perception regarding toxoplasmosis among seropositive pregnant women in Northern Upper Egypt. Infection, 6(1):1-19.

46. Al-Khalifa, I., Al-Shaikh, M.A., Al-Jumaah, R.S., Jarelnabi, A. and Hussein, M.F. (2018) Serological prevalence of abortifacient agents in female Mijaheem camels (Camelus dromedarius) in Saudi Arabia. J. Anim. Res., 8(3): 335-343.

47. Lashari, M.H., Ghouri, M.T., Akhtar, M.S., Kamran, Z., Chaudhari, M.S., Ayaz, M., Farooq, A.A. and Sarwar, G. (2018) Hematological and biochemical alterations associated with toxoplasmosis in dromedaries (Camelus dromedarius) habitating in Cholistan desert of Bahawalpur, Punjab, Pakistan. J. Anim. Plant Sci., 28(4): 1043-1048.

48. Must, K., Hytönen, M.K., Orro, T., Lohi, H. and Jokelainen, P. (2017) Toxoplasma gondii seroprevalence varies by cat breed. PLoS One, 12(9): e0184659.

49. Faraz, A., Younas, M., Pastrana, C.I., Waheed, A., Tauqir, N.A. and Nabeel, M.S. (2021) Socio-economic constraints on camel production in Pakistan's extensive pastoral farming. Pastoralism, 11(1): 1-9. 
50. Tibary A, Fite C, Anouassi A, Sghiri A (2006) Infectious causes of reproductive loss in camelids. Theriogenology, 66(3): 633-47.

51. Tenter AM (2009) Toxoplasma gondii in animals used for human consumption. Mem Inst Oswaldo Cruz, 104 (2):364-9.

52. Dubey, J.P. (2016) Toxoplasmosis of Animals and Humans. CRC Press, Boca Raton, Florida

53. Oliveira-Junior, A.A., Tavares-Dias, M. and Marcon, J.L. (2009) Biochemical and hematological reference ranges for Amazon freshwater turtle, Podocnemis expansa (Reptilia: Pelomedusidae), with morphologic assessment of blood cells. Res. Vet. Sci., 86(1): 146-151.

54. Raisinghani, P.M. and Lodha, K.R. (1980) Prognostic values of some haematological and biochemical parameters of camels affected with surra following the treatment with antrypol, antrycide mehtyl sulphate, naganol and berenil. Indian Vet. J., 57(6): 479-484.

55. Partani, A.K., Rai, A.K., Kumar, D., Katari, A.K. and Swarnkar, C.P. (1994) Haematological and biochemical changes in camel naturally infected with gastrointestinal nematodes. J. Camel Pract. Res., 2(1): 33-36.

56. Chaudhary, Z.I., Iqbal, J., Raza, M. and Kandeel, M.I. (1996) Haematological and biochemical studies on toxoplasmosis in racing camels a preliminary report. J. Camel Pract. Res., 3(1): 7-9.

57. Ahmad, S.H., Butt, A.A., Muhammad, G., Athar, M. and Khan, M.Z. (2004) Haematobiochemical studies on the haemoparasitized camels. Int. J. Agric. Biol., 6(2): 331-334.

58. Sazmand, A., Rasooli, A., Nouri, M., Hamidinejat, H. and Hekmatimoghaddam, S. (2011) Serobiochemical alterations in subclinically affected dromedary camels with Trypanosoma evansi in Iran. Pak. Vet. J., 31(3): 223-226.

59. Salaheldin, E.A., Wahbi, A.G. and Idris, O.F. (1979) A note on the haematology of adult Sudanese dromedaries. In: The Camelid, an All-purpose Animal. Proc. Khartoum.1: 444-448.

60. Iewida, S.Y. and Cabanacan-Salibay, C. (2010) Serologic detection of Toxoplasma gondii infection in stray and household cats and its hematologic evaluation. Sci. Med., 20(1): 76-82.

61. Wang, Z., Zhang, D.X. and Zhao, Q. (2015) Infectionstimulated anemia results primarily from interferon gamma-dependent, signal transducer and activator of transcription 1-independent red cell loss. Chin. Med. J., 128(7): 948-955.

62. Atmaca, H.T., Öcal, N., Babür, C. and Kul, O. (2012) Reactivated and clinical Toxoplasma gondii infection in young lambs: Clinical, serological and pathological evidences. Small Rumin. Res., 105(1-3): 335-340.

63. Atmaca, H.T., Gazyagc1, A.N., Canpolat, S. and Kul, O. (2013) Hepatic stellate cells increase in Toxoplasma gondii infection in mice. Parasit. Vectors, 6(1): 1-6.

64. Mordue, D.G., Monroy, F., La Regina, M., Dinarello, C.A. and Sibley, L.D. (2001) Acute toxoplasmosis leads to lethal overproduction of Th1 cytokines. J. Immunol., 167(8): 4574-4584.

65. Adeyemi, O.S. and Akanji, M.A. (2011) Biochemical changes in the kidney and liver of rats following administration of ethanolic extract of Psidium guajava leaves. Hum. Exp. Toxicol., 30(9): 1266-1274.

66. Muhsin, S.S., Jafar, E.H. and Jafar, N.S. (2013) Biochemical study on the effect of Toxoplasma gondii on liver function in women. Iraqi J. Vet. Med., 37(2): 257-260.

67. El-Sayed, N.M., Ramadan, M.E. and Ramadan, M.E. (2016) Toxoplasma gondii infection and chronic liver diseases: Evidence of an association. Trop. Med. Infect. Dis., 1(1): 7.

68. Nurgul, A., Miyase, C., Bayram, G., Ruhi, K., Gazyağci, A.N., Tark, A.H. and Sila, C. (2015) Evaluation of oxidative stress, hematological and biochemical parameters during Toxoplasma gondii infection in gerbils. Ankara Univ. Vet. Fakult. Derg., 62(3): $165-170$.

69. Elmenyawe, S.M., Abdelrahman, M., Aal, A.M.I., Kamal, A. and Snousi, A.S. (2010) Prevalence of some protozoa and its effects on biochemical changes in goats in Cairo, Marsa Matrouh, and El-Wadi El-Gadid Provinces. Egypt. J. Comp. Pathol. Clin. Pathol., 23(1): 102-115.

70. Yarim, G.F., Nisbet, C., Oncel, T., Cenesiz, S. and Ciftci, G. (2007) Serum protein alterations in dogs naturally infected with Toxoplasma gondii. Parasitol. Res., 101(5): 1197-1202.

71. Amany, M., Eid, R.A. and Fahmy, B.G. (2010) Biochemical studies on the effect of Toxoplasma infection on liver and kidney functions in mice. Egypt. J. Comp. Pathol. Clin. Pathol., 23(1): 174-185.

72. Abdulameer, N.A. (2020) The effect of toxoplasmosis on some blood parameters of gravid women in Al-Diwaniyah city. Int. J. Pharm. Res., 12(2): 5-10.

73. Sowjanya, M., Kumar, K.K. and Sunita, K. (2013) Assessment of biochemical variations and splenomegaly during Falciparum malaria in mice model. Bioscan Int. $Q$. J Life Sci., 8: 925-929.

74. Anosa, V.O. (1988) Haematological and biochemical changes in human and animal trypanosomiasis. I. Rev. Elev. Med. Vet. Pays Trop., 41(1): 65-78. 